\title{
The Methods and IT-Tools Used in Higher Education Assessed in the Characteristics and Attitude of Gen Z
}

\author{
Szabó, Csilla Marianna, Bartal, Orsolya, Nagy, Bálint \\ University of Dunaújváros, Táncsics út 1/A, H-2400 Dunaújváros, Hungary \\ e-mail: szabocs@uniduna.hu,bartalorsolya@uniduna.hu,nagyb@uniduna.hu
}

\begin{abstract}
In the era of digital transformation, some questions occur whether the teaching methods used in higher education are suitable for the students belonging to generation $\mathrm{Z}$ or these methods are appropriate enough to make them more attentive or motivated. The diverse methods of information technology have already spread into university education and a pedagogical paradigm shift can be perceived. The latest methodology, like project method, e-learning, BYOD, gamification, MOOC are available in higher education as well; however, it is a question to what extent teachers apply these methods in their teaching process. The new techniques not only make the students more motivated but also enhance them with those sorts of skills that are indispensable to be successful in the field of labor. The research was aimed to find answers about how much engineer students are satisfied with the training they are given in higher education in the $21^{\text {st }}$ Century, what kind of attitude they have towards educational technology.
\end{abstract}

Keywords: teaching-learning startegies and techniques; up-to-date teaching methodology; educational technology; generation $Z$ learning style and attention; engineering education; career development

\section{Introduction}

In our digitalized world, it is beyond dispute that higher education has to keep pace with the methods and educational technology used widely in the $21^{\text {st }}$ Century. Also, it is a contemporary and relevant issue that university professors have to adjust themselves and accept the fact that the students belonging to Gen $\mathrm{Z}$ require other teaching aspects and approaches. As far as the survey presented in this paper is concerned, we would like to show how engineer students see their education at the university these days.

The visions and attitudes of Generation $\mathrm{Z}$ are completely different from that of the previous generations not to mention their values of life and the priorities they set for themselves. The problem-solving methods they use and multitasking operation 
are just two of the features the would-be engineers have and use during their studies while fulfilling their tasks [1-3].

In the paper, after reviewing the relevant theoretical background we are introducing research carried out in two countries, the goal of which was to find out the correlation between the attitudes and features of Gen $\mathrm{Z}$ and the digital technology used in higher education.

\section{Theoretical Background}

\subsection{Modern Learning Theories and Techniques}

At the end of the $20^{\text {th }}$ Century, but mostly at the beginning of the $21^{\text {st }}$ Century, the changes both in science and in technology created a situation when new learning circumstances and merely new spaces occurred that implicitly altered the methods, the tools, and the techniques of learning. For these reasons, learning theories have gone through a change and new ones appeared or at least they are constantly developing as the circumstances and people are transforming. Experts in education have always been interested in the objectives and reasons for behavior, acts, processes, etc. since mankind teaches younger ones to gain information about the surrounding world. In the following, some modern learning theories will be listed and shortly described to help better understand the mechanism of educational procedures in the latest few decades.

Out of the $20^{\text {th }}$ Century learning theories regarding Generation $\mathrm{Z}$ and their learning techniques, it is worth mentioning constructivist learning theory and connectivist pedagogical attitude [4-6].

\subsection{Contemporary Teaching-Learning Strategies and Methods}

We are going through a digital transformation in every step of daily life. The digital transformation is literally at hand in the shape of smartphones, laptops, and tablets. [7]. As Racsko determines the process of digital transformation is the fact while ICT-literacy is materialized by the usage of human support technology tools via the spread and the integration of the technologies of the information society. [8] In the course of this procedure, the tools and their virtual environments are highlighted, and the competencies are emphasized with which these can be applied confidentially to the teaching-learning procession creating new learning environments for educational goals [9]-[11]. With this phenomenon not only the learning theories have altered much, but also the teaching-learning strategies and techniques have gone through a huge change [12]. 
We as educators and experts have to be aware of the fact that those young people studying at the universities these days have grown up in a glaringly different learning environment if we compare it with the classrooms of two decades ago. [13] The question arises, is Gen $\mathrm{Z}$ using these tools and opportunities effectively for reaching the desired goal for their education and for gaining their future professions.

In the following, we would mention some contemporary teaching-learning strategies and techniques that are used with success in educational practice following the list of strategies offered by Muhi et al., [14]. Firstly, Self Training, when students acquire the material according to their own pace and the most suitable methods for them [15]. This strategy requires the tools, resources, and aids that are inevitable for accessing new knowledge. Secondly, Experimental Learning, which can be perceived as a cyclical development process in which the participants gain some experience then it is interpreted and analyzed [16]. In this way, the individuals' activity is formed and the gained knowledge is tried out in a new environment. After this, the cycle restarts. Thirdly, Free, Independent Learning, when there is no formal space or control in the procedure [17]. The only thing that determines the process is the skills and opportunities of the learner. The fourth is the On the Job Training. This strategy is one of the most goaloriented teaching strategies, it is like an internship. The fifth is External Learning, in which the participants do not have to enroll in a formal course rather the learning process is acquired via e-learning or distant learning methods. Distance Learning or Distance Education is very similar to the previous one but its feature is that the teaching-learning mechanism can be solved with the help of an IT device that can be the tool between the teacher and the student. The following is Digital Education in which the medium is the technical device via which the knowledge is gained and this medium is primarily a computer and software [18]. Last but not least, the Blended Learning method, which is about mixing the abovementioned possibilities to reach a complex mixture of traditional and digital methods [19]. Using mobile tools (laptop, tablet, mobile phone) in the process of education is diversified and at the same time an exciting, challenging possibility in the hand of educators. In higher education MOOC (Massive Open Online Courses) [20] is common but we have to admit that it is popular mostly abroad not in Hungary.

Another commonly used technique is BYOD (Bring Your Own Device) when the students' own devices are used in the classroom for educational purposes [21]. It can also be a path to decrease the digital divide, mostly when the tool is provided by the institution. In Hungary there are two models how the abovementioned method is applied by the institutions: 1 . the mobile tool is owned by the school, 2. the tool is owned by the student. The most common and realistic way concerning Hungarian society is the first version when the mobile tools (laptop, tablet) are owned by the institution. Regarding higher education, the access of the Internet and $\mathrm{WiFi}$ is provided freely for users. University students have become 
used to accomplishing tasks with the help of their smartphones, laptops, and tablets.

Using different kinds of platforms and tools for learning, educators need to motivate students in some other ways, as well. Generation $\mathrm{Z}$ has different ways of motivating and learning procedures. Motivational methods, such as gamification, have become more and more popular, which are built in the learning pursuit and can develop students' digital competencies while using the elements of the game to increase learners' commitment to learning [22]. Gamification could be a part of the motivational procedure which can enrich the teaching-learning mechanism. These days there are best practices in higher education for using the game for enhancing students' efficiency in learning used by some exceptional educators who want to apply new approaches for motivating the Generation $\mathrm{Z}$ students in the classroom and outside of it.

We must admit that applying the above-described methods requires additional competencies from teachers besides the basic ones. Digital competence is one of the competencies teachers need if they wish to use modern techniques embedded in their lessons [23].

According to Ala-Mutka [24], digital competence is far more than just one skill. It involves more additional skills, such as communication skills, cooperation [25], creativity, critical thinking or even problem solving [26]. In the classrooms, ICT devices as completion of traditional methods are getting more and more popular to be integrated into the educational process by teachers [15]. The question occurs whether teachers are skilled enough to use these tools in class or not. In the USA, the standards that are appropriate for measuring and qualifying both teachers and teacher training institutes have been mapped out [27].

From another aspect, Prievara suggests that teachers need five important skills in the $21^{\text {st }}$ Century classroom: collaboration, building knowledge, using ICT tools, problem-solving and innovation, and self-control. [28] Firstly, the participants in the classroom (or with the help of modern technology outside of it) should work together, collaborate to reach the desired aim. Building knowledge must be an evident terminology for outsiders but it is meant in a way that the student is only given the information and he/she has to reproduce it again while creating new knowledge in merely novel situations. The usage of ICT devices in our digitalized world is inevitable (MaxWhere3D platform, gamification, BYOD, etc.). Problem solving and innovation are the two skills that were always in the education needed to help the process. Teachers need to be innovative and ready to solve occurring problems from time to time. Reflecting on our work, giving feedback to selfdevelopment means self-control at the same time. Teachers need to adjust to digital transformation to be able to understand future generations. 


\subsection{Generation $\mathrm{Z}$ Learning Style and Attention}

Today students in higher education belong to Generation Z. However, there are debates about clustering generations and there are also some categorizations made by researchers based on the date of birth of people. What is sure that nowadays learners' views of life, expectations, values, and norms are different from that of the previous generations. Although former generation members often see its drawbacks, we do not have to think as if it were either advantageous or disadvantageous. Only we need to adjust and accept this development and try to understand and help the up-growing generation.

According to Jukes and Dosaj [29], the digital inborn students can be characterized as follows: they can access information via different media; they use simultaneous information processing and as it is often called multitasking; this generation mainly prefers pictures, sound, and videos instead of texts; they apply non-linear elaboration; gen Zers are adopted to the preference of simultaneous interactions; they need inner learning motivation; they are immediate feedback orientated, and last but not least they prefer useful, immediately used information. Generation Z's learning style and focus are varied. Based on surveys, it can be stated that they did not have an off-line childhood. In the virtual world, they had to get used to immediate feedback, accessing information quickly and that is why they expect the same circumstances from the real - off-line - world, too. [30]

Nowadays students are connected to each other mostly $7 / 24$ in the online space. They can also perfectly surf the net and use devices for their own goals and everything is just from one 'click' from them. They are able to use digital devices naturally but it is not evident if they are aware of some of its required competencies, such as ethical behavior in the virtual world, protection of data, understanding deeply the content of a text, accessing relevant and not fake information, just to mention some. [31] Although there are substantial challenges working with Generation $\mathrm{Z}$ in education, this new situation espouses a wide range of potentials and numerous questions to investigate and answer in order to have all its advantageous virtue.

Today one of the biggest and could hardly be answered questions is how a teacher could be able to grab students' attention in class, how they are able to raise their interests [30]-[32] There are surveys to examine the use of the collaborative method in the altering learning environment, which are used effectively with the help of innovative tools and methods to enlarge the learning space and adjust to the features and needs of Generation Z [33].

In some cases, new models are described to support the university students' attention, inner drive and effectiveness in their studies. For example, Benedek and Molnár presented in their study an innovational ICT-based infrastructure and its affects on collaborative e-learning platform used in higher education with students belonging to Generation Z. [34] Another tool that perfectly suits the needs of 
Generation $\mathrm{Z}$ is $3 \mathrm{D}$ Internet, which provides immersive online experience for the users [3]. The digital materialization of 3D Internet in education is the software MaxWhere, which has been used in some universities, including the University of Dunaújváros. MaxWhere is a 3D system, developed by Hungarian scientists, which not only allows uploading and storing both 2D and 3D objects, from texts to audio and video files, but also makes the teaching-learning process more effective with better remembering and shortening collaborative workflow time. [35] Most of the time teachers have to face the fact that students are becoming impatient if they do not get immediate feedback, quick information as they become used to during their daily online presence. [28] These e-learning spaces can have the solution to this problem and can equal the division between generations, too.

Using the Internet and searching for information on the world wide web influences Generation Z brain activity. According to professor Small's experiment [36], in the brain of people who spent minimum one or two hours a week searching on the Internet changes could be detected: their brain activity became more widespread on a particular territory; neural pathways supporting traditional mental functions, such as book reading, become weaker, while new connections are forming [37]. Small [36] declares that searching on the Internet make human brain work, just like doing crossword puzzle; however, that intensive brain work may prevent deep thinking and learning if it becomes the primary way of thinking. Continuous mental coordination and decision making derive human attention from the interpretation of texts, so while reading on the Internet, we sacrifice our skill that enables deep reading, and we could become the pure decoders of information. [37]. Based on the studies, Szöke-Milinte [38] states that the attention of Generation $\mathrm{Z}$ is changing.

Working memory, as a sort of short-term memory, plays a significant role in transforming information into long-term memory, and so in formulating our knowledge. The working memory can store only a small amount, 7 pieces, of information. On the other hand, information stored only in the working memory quickly disappears. The depth of our intelligence depends on the fact whether we are able to transform information from working memory into long-term memory. [37] Due to web 2.0 applications, people, especially Generation $\mathrm{Z}$ members, meet the flood of information that working memory is unable to handle it and could transfer only a small amount of information into the long-term memory. Moreover, the transferred information is so diffuse and mixed that the brain cannot find and recall it. It means that the working memory is so burdened that it cannot maintain its ability to store and elaborate information, to fit new information into the long-term memory, and to form links between the new and the old information [38]. 


\section{The Research}

\subsection{The Research Process and Method}

The international research was conducted at a Russian and a Hungarian university. The Russian, the Ural Federal University is a huge institute with several tens of thousands of students and is situated in Ekaterinburg, while the Hungarian one, the University of Dunaújváros is a small university with about 1,600 students. However, both higher education institutes have an engineer study program. The survey was carried out in spring 2019 with a self-administered questionnaire among the engineer students (mechanical and IT engineering) who study in the third and fourth forms of their university training. The questionnaire was elaborated by the Russian colleagues in the Russian language and was translated then into Hungarian and adapted (and a bit modified) to the Hungarian higher education system and its attributes. Russian students were given the digital form of the questionnaire, while Hungarian students answered a paper questionnaire. After receiving all the answers, the data from the two subgroups were incorporated into one united file. The analysis of the data was done by SPSS 22.0 statistical program.

The research is considered to be a pilot one, as the sample is not so big: altogether 117 engineer students took part in the research from the two countries; the number of the Hungarian sub-sample is 64 people, while that of the Russian one is 53 people. Regarding respondents' gender distribution, there is a difference between the two sub-sample: in the Russian subsample, the ratio of males and females was nearly the same (52.8\% males, $47.2 \%$ females). On the other hand, the Hungarian sub-sample presents a much more uneven distribution: $90.6 \%$ of all Hungarian engineer students were males. The fact that male students are overrepresented not only in engineer study programs and careers, but in most STEM training and jobs may refer to the attitude of Hungarian society towards STEM subjects, study programs, and jobs.

\subsection{Research Results}

The questionnaire wanted to receive answers about engineer training from several different aspects:

- on the basis of which factors students choose the higher education institute;

- what factors have an impact on the quality of the training;

- $\quad$ how high the prestige of engineer training; 
- $\quad$ how easy to find a job after taking the degree;

- what priorities they have regarding their future professional and personal life.

During the process of choosing a higher education institute, students consider many several aspects to make their decision. Respondents had to decide whether the given factors play a very important or not important role in the decision making process. The results of the questionnaire show difference between the opinion of Hungarian and Russian students: while $66 \%$ of Russian students stated the prestige of university was very important, only $45 \%$ of Hungarian students thought the same. However, Hungarian students found material factors much more important: about two-third (73.4\%) of them implied that the factor 'after taking the degree to find a good and well-paid job' is significantly important - while about half $(53 \%)$ of Russian students evaluated this factor very important. Taking into consideration the influence of the family, less than $10 \%$ of Russian students chose the university due to their relatives' opinions who studied there earlier. On the other hand, this variable was considered very important by $25 \%$ of Hungarian students.

Analyzing the result with crosstable, the chi-square test indicated a significant difference between the opinion of Russian and Hungarian students in case of five variables: the prestige of the university $(\chi 2=7.855 ; \mathrm{p}<0,05)$, the costs of the training $(\chi 2=10.329 ; p<0.01)$, after the degree it is easy to find a good and wellpaid job $(\chi 2=0.001 ; p<0.01)$, having a kind of privilege in admission $(\chi 2=7.486$; $\mathrm{p}<0.05)$, and the high quality professional practical training $(\chi 2=8.511 ; \mathrm{p}<0.05)$. While the factors of the prestige of the university and having a privilege were significantly more important to Russian students, significantly more Hungarian students prioritized the costs of the training and gaining a well-paid job after graduation. Although more Hungarian than Russian students declared that highquality practical training is very important, the difference between the two subsamples is only $9 \%$. Nevertheless, twice more Russian $(41.5 \%)$ than Hungarian (18.8\%) students answered that they cannot decide the significance of this factor. Based on the results, it can be stated that Hungarian students are more committed to the significance and the relevance of professional practical training and internship.

The quality of higher education training can be influenced by several different factors. Researchers listed some of them in the survey, and students had to indicate what importance they assign to each variable (very important - not important - cannot say). Regarding these variables, the opinion of Hungarian and Russian students demonstrated very few differences. Both subsamples labeled the technological base of the university and the availability of laboratories very important, as well as the close connection between the knowledge gained at the university and the professional requirements of the labor market. The former factor was considered very important by the $78 \%$ of Hungarian and $89 \%$ of 
Russian students, while the latter variable was implied really important by $73 \%$ of Hungarian and $91 \%$ of Russain students.

However, there are some differences between the two sub-samples: the chi-square test showed a significant difference between Hungarian and Russian students' opinions in the case of 5 factors out of the 12. Significantly much more Hungarian (64.1\%) than Russian (39.6\%) thought it very important that students can study both full and part-time and can combine work and study without a negative impact on their advancement $(\chi 2=7.237 ; \mathrm{p}<0.05)$. On the other hand, significantly more Russian (83\%) than Hungarian (53.1\%) students find it very important that partner employers should be involved in the training programs. At the same time, five times more Hungarian $(28.1 \%)$ than Russian $(5.7 \%)$ students evaluated this factor as not important $(\chi 2=13.078 ; \mathrm{p}<0.01)$. Moreover, more Russian $(72 \%)$ than Hungarian (41\%) students consider that the opportunity to participate in student mobility programs is very important. This factor is evaluated as not important by one third $(36.5 \%)$ of Hungarian students - more than three times more than the Russian ones $(11.3 \%)(\chi 2=12.5348 ; \mathrm{p}<0.01)$.

Table 1

Factors influencing the quality of education - comparison of Hungarian and Russian students

\begin{tabular}{|l|c|c|}
\hline \multicolumn{1}{|c|}{ Factors influencing the quality of education } & Hungarian & Russian \\
\hline Education is available in various forms. & $64 \%$ & $40 \%$ \\
\hline Opportunity to study under an individual curriculum. & $61 \%$ & $62 \%$ \\
\hline Opportunity for professional development during internships. & $75 \%$ & $76 \%$ \\
\hline Existence of students' councils and professional unions. & $31 \%$ & $25 \%$ \\
\hline Availability of massive open online courses. & $41 \%$ & $51 \%$ \\
\hline $\begin{array}{l}\text { Availability of inter-university student exchange programs } \\
\text { (Erasmus). }\end{array}$ & $41 \%$ & $72 \%$ \\
\hline $\begin{array}{l}\text { Connection of the knowledge gained with the real work in the } \\
\text { profession. }\end{array}$ & $73 \%$ & $91 \%$ \\
\hline Individual work of teachers with students. & $59 \%$ & $72 \%$ \\
\hline $\begin{array}{l}\text { Technology base, availability of modern equipment in laboratories } \\
\text { and classrooms. }\end{array}$ & $78 \%$ & $89 \%$ \\
\hline
\end{tabular}

Regarding two factors ('the opportunity to study according to individual curriculum' and 'supplementing training programs with e-learning and distance learning technologies'), the chi-square test presented a significant difference between the two sub-samples. Examining the details of the crosstable analysis, it can be stated that a very small difference can be found between the number of Hungarian and Russian students evaluating these factors very important - in the former case $1.4 \%$, in the latter one $11.6 \%$. However, nearly or exactly three times more Hungarian than Russian students found these factors not important that is why the difference between the two sub-samples was a significant opportunity for an individual curriculum $(\chi 2=7.869 ; \mathrm{p}<0.05)$; availability of e-learning and distance learning technologies $(\chi 2=10.702 ; p<0.01)$. 
The results raise some questions about the attitude of Hungarian students. Why do they not appreciate the involvement of partner employers in their training program? What is more, in Hungarian higher education institutions, especially, at the University of Duanújváros, the process of incorporating industrial and business companies into university programs has started: students do laboratory work in special labs supported and maintained by well-known and significant business employers, the employees of some IT companies have academic lessons, and students have the opportunity to do dual raining throughout their university training. That is why it is not clear why they did not find this factor important. On the other hand, Hungarian students are not really interested in student mobility programs either, they are less willing to take part in them. The reason behind this result could be the fact that many Hungarian students' foreign language proficiency is not high enough to learn professional subjects.

Most of today university students, especially the ones who study in full-time education, belong to Generation Z. Being born in the online world, the members of this generation have got used to the speed of the web and instant feedback in social media, and they expect similar conditions in the off-line world, too. One of the biggest challenges of today's education system is how teachers could catch and maintain the young generation's attention that was developed in the fast and instant online world with a slower pace and delayed feedbacks of the off-line reality. As Generation $\mathrm{Z}$ uses digital technology without any difficulties both for entertainment and for learning; multitasking, as their usual existence in everyday life, is built in their learning process; moreover, as they prefer learning in groups and with gamification methods [39], working interactively and being in contact all the time, they find reasonably boring usual and old-fashioned school activities and $20^{\text {th }}$-Century teaching-learning methodologies. If teachers do not want to compete with students' digital gadgets and their activities in the virtual space, they should acquire how to use $21^{\text {st }}$-Century teaching techniques and how to use smart devices for learning in the framework of the education system.

Researchers asked students' opinions on how frequently various teaching methods and activities are used in education and how effectively they develop students' competencies. Respondents had to evaluate 9 different methods on a four-grade scale regarding the frequency of their usage. Number 1 means they are not familiar with the method/activity, while number 4 means it is commonly used in the teaching-learning process. According to the result of Figure 1, there are differences between Hungarian and Russian university practice using various methods and activities. In the Russian university, the most frequently used method is project work (3.77) but professors frequently involve e-learning (3.38) and online courses (3.53) in the learning process. On the other hand, these methods are less frequently used in the Hungarian university; however, their value is nearly 3.00 or over 3.00 , which means that they are used minimum sometimes.

Regarding different forms of learning activity, such as peer, active, and self-paced learning, Hungarian students use it more often than the Russian ones. 
The question is if students exactly knew the definition of these concepts when they answered the question. As for peer learning, it refers to the activity when students work collaboratively and cooperatively supporting each other in the learning process and taking the responsibility for their own and their peers' learning. The forms of peer learning are peer support groups, peer teaching, peer tutoring, and peer-assisted learning. [40] Active learning implies students' activity when they do meaningful learning activities and personally engage in the learning process in the form of short course-related individual or small-group activities. Active learning is usually contrasted to traditional professor-led lectures, where students generally passively receive information [41]-[42] The concept of selfpaced learning means more than just student's decision when, how quickly, and in what orders they learn the material. Self-paced learning refers to a learning process, where the curriculum is determined by students' abilities rather than being fixed by the teacher [43] and dynamically generated by students themselves, according to the fact of what they have already learned [44]. Researchers think that while peer and active learning were properly understood by the respondents, they did not really know the essence of self-paced learning.

The results show that Hungarian students are more frequently involved in modern learning activities: peer, active, and self-paced learning. As many Hungarian students belong to the historically based student community where they follow, preserve, and practice very old student traditions from the era of Queen MariaTeresia, they support their student-fellows in learning, too. Moreover, peer learning appears in virtuality as well as students often have special closed groups in social media, where they discuss and share learning materials. However, researchers think that under the concept of self-paced learning students understood only the fact that when, how long, and how intensively they could learn. The curriculum at the Hungarian university is rather fixed, regarding the subjects, the order of subjects, the compulsory materials, and competencies that must be acquired by the end of each semester, which means students cannot modify it. That is the high frequency received from the Hungarian questionnaire could be deceiving.

What is annoying according to the results that gamification is significantly rarely used by both Hungarian and Russian universities. Gamification is a technique when gameplay elements are included and used in non-game settings and processes to engage and motivate participants Although it was first applied in the HR field, it is now used in the education process, too. According to the results, some students do not know this method at all and many of them have not even heard about it nor have they ever been involved in a lesson like that. The question is raised again: whether students properly know what gamification means. Many teachers use one or more learning applications, such as LearningApps, Kahoot, Mentimeter, built in the teaching process. According to literature, the teaching process using applications sometimes cannot be called gamification. 


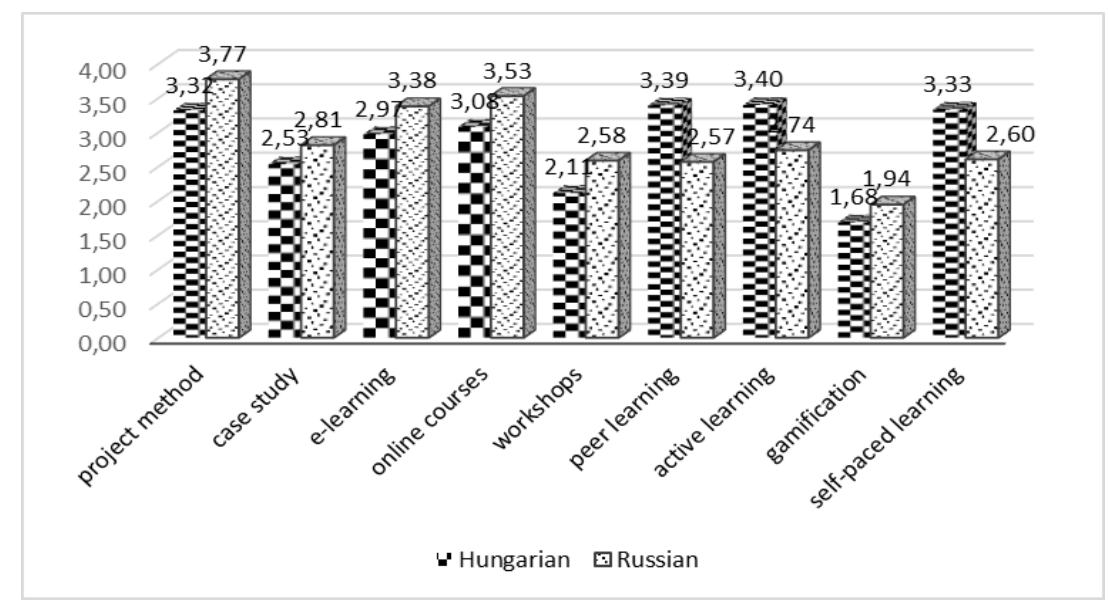

Figure 1

Frequency of using methods

Based on broad interpretation, gamification is called when game-like elements are regularly incorporated in the teaching-learning process, and their results form a part of the final assessment; e.g. the result of Kahoot done in each lesson gives a particular proportion of the final grade. On the other hand, real gamification is considered when the whole teaching process is built from game-like elements: students collect points. and on the basis of the number of their points they could reach a particular level - while competing individually or in groups with their peers. [21] Regardless of the fact whether students know the proper definition of gamification or not, the result deserves attention: out of the 117 studentrespondent, only 6 of them mentioned that gamification is a common practice and another 24 students implied that this method has sometimes been used.

Comparing the frequency of using methods and learning activities, differences can be found between Hungarian and Russian students' opinions. Crosstable analysis and chi-square test presented that in case of seven out of the nine variables, the difference is significant: project work $(\chi 2=28.229 ; \mathrm{p}<0.001)$, e-learning $(\chi 2=8.644 ; \mathrm{p}<0.05)$, online courses $(\chi 2=13.357 ; \mathrm{p}<0.01)$, and workshops $(\chi 2=16.399 ; \mathrm{p}<0.01)$ are significantly more frequently used at the Russian university. On the other hand, peer learning $(\chi 2=21.764 ; \mathrm{p}<0.001)$, active learning $(\chi 2=13.608 ; \quad \mathrm{p}<0.01)$, and self-paced learning $(\chi 2=14.001 ; \mathrm{p}<0.01)$ are significantly more often appear in the Hungarian teaching-learning process. Regarding workshops and gamification, there is no significant difference between the two sub-samples' opinions.

Except for how frequently methods and activities are used in the teaching-learning process, the other essential factor is how effective they are, especially what students think of the efficiency of various methods. Researchers listed 10 variables and students had to evaluate them on a ten-grade scale based on their 
efficiency, where 1 means the least and 10 - the most effective. The list contained both traditional higher education teaching-learning activities, the ones referring to practice, and some more up-to-date ones, such as examinations and lectures, laboratory works and field experience, as well as online courses and projects. Since the Russian and the Hungarian higher education systems work in a bit different way, some original Russian variables must have been modified and adjusted to the Hungarian system. While in the Russian questionnaire, researchers listed Masterclasses (Мастер-классы) and Business games (Деловые игры), in the Hungarian questionnaire, researchers mentioned instead College for Advanced Studies (so-called: Szakkollégium) and Mobile learning (using laptops, smartphones in education). The analysis of the results of the whole sample is given without these two variables. However, the results of the two different variables will be mentioned separately by the nationalities.

Table 2

Effectiveness of methods and activities - whole sample

\begin{tabular}{|c|c|c|c|c|c|c|c|}
\hline lectures & $\begin{array}{c}\text { online } \\
\text { courses }\end{array}$ & $\begin{array}{c}\text { practi- } \\
\text { cal } \\
\text { lessons }\end{array}$ & $\begin{array}{c}\text { labora- } \\
\text { tory } \\
\text { works }\end{array}$ & $\begin{array}{c}\text { individual } \\
\text { work }\end{array}$ & projects & $\begin{array}{c}\text { intern- } \\
\text { ship, dual } \\
\text { training }\end{array}$ & $\begin{array}{c}\text { exami- } \\
\text { nations }\end{array}$ \\
\hline 6.59 & 6.06 & 7.29 & 7.18 & 7.11 & 7.33 & 7.54 & 6.11 \\
\hline
\end{tabular}

According to all students' opinions, internship, dual training (7.54), and practical lessons (7.29) are consideredthe most effective learning activities; while examinations (6.11) and online courses (6.06) the least effective ones. As the research was conducted among engineer students, their opinions present that they prefer the practical parts of their training and suppose them the most significant and effective ones. On the other hand, the traditional teaching-learning activity, examination, was thought to be not really effective. However, it must be mentioned that online courses, which are considered an up-to-date method, are assessed the least effective. In the background of the low score, the reason can be that students connected online courses with theoretical subjects, and they believe that practical elements are much more important for their future career.

Comparing the Hungarian and Russian results, there are some differences, they are not significant, though. Hungarian students regard the practical part of the training (practical lessons and laboratory works) as more effective, while Russian students prefer projects and individual work. On the other hand, Hungarian students think examinations and online courses more effective than Russian ones. Moreover, online courses are believed by Russian students to be the least effective of the seven factors. This result is a bit surprising as online courses are rather frequently used in the Russian university: the frequency score is 3.53 on the four-grade scale - the second highest score out of the listed 9 variables (Figure 1). It means that although online course education is often used by the Russian university, it is considered not really effective by students. 
As far as the two different variables are concerned, the Russain questionnaire contained master classes and business games. They were evaluated by students medium effective and received scores 6.70, 6.89. Hungarian students evaluated the variables of College for Advanced Studies and Mobile learning. According to their opinion, these activities are thought to be the least effective out of the ten ones: mobile devices: 6.11, college for advanced studies 5.79. Regarding mobile learning, the result is not surprising: activities that can be linked to mobile learning (e-learning and gamification) is not frequently used in the teaching process. Students do not have enough experience with these techniques so they do not evaluate their effectiveness high. However, colleges for advanced studies are in practice at the Hungarian university, especially in the fields of engineering and IT. The problem might be that only a few students are involved in their work and the majority do not realize its effectiveness in the learning process.

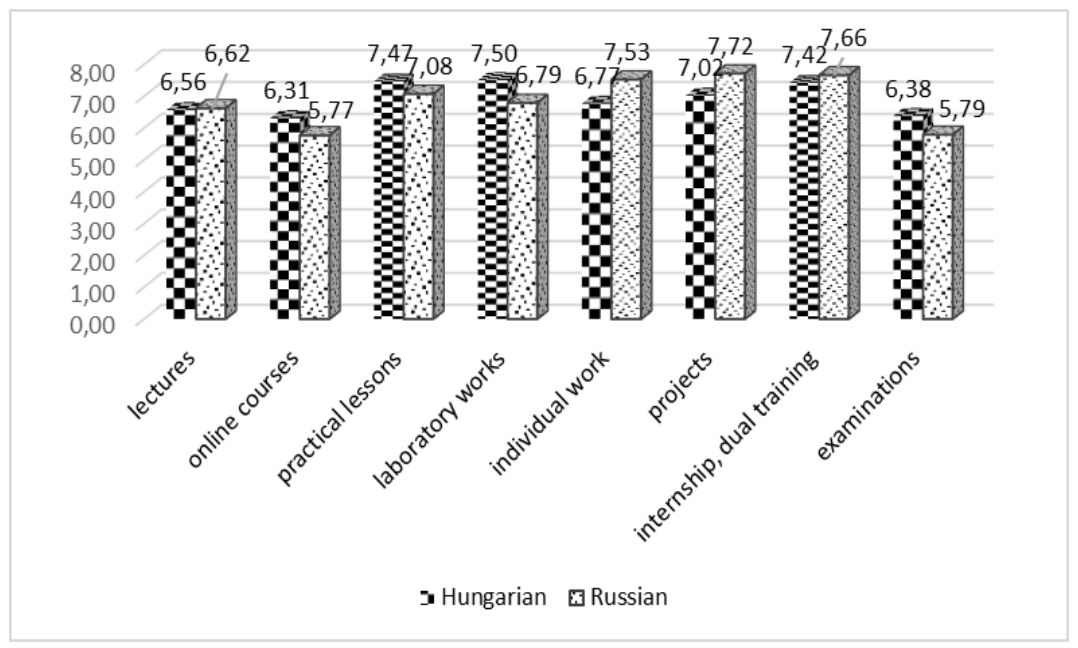

Figure 2

Effectiveness of activities - comparison of Hungarian and Russian data

Even the bar chart (Figure 2) shows that there are small differences between the evaluation of Hungarian and Russian students. Comparing the result with a crosstable, the chi-square test indicated that there is no significant difference between the two sub-samples.

The data implies that Hungarian students appreciate the practical parts of their training: practical lessons, laboratory work, internships. Examining the result of method and activity effectiveness, especially the proportion of students who assessed effectiveness very high (i.e.: gave 8,9 , or 10 points), the tendency is clear. Table 3 represents the summarized percentage of the highest three categories. 
According to the result, Hungarian students considered that the most effective activities are practical lessons, work in the laboratory, and internships or dual training. Comparing these data with the means of the ten-grade scale question, similar opinions can be recognized; the same three variables show the highest mean: practical lessons (7.47), laboratory works (7.5), and internships and dual training (7.42). Comparing these results with the factors influencing the quality of the training, Hungarian students emphasized the significance of the practice, too. The factors that are evaluated very important by most students are the opportunity of professional development during internships, connection of the knowledge gained with the real work in the profession, and technology base of the university, availability of modern equipment in laboratories and classrooms. All these results indicate that Hungarian students find the practical elements of the training the most significant and the most influential in the quality of the training and the most effective in their professional development.

Table 3

Effectiveness of activities by Hungarian students - highest three categories summarized (\%)

\begin{tabular}{|c|c|c|c|c|c|c|c|c|c|}
\hline 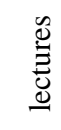 & 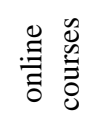 & 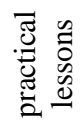 & 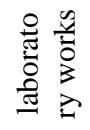 & 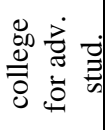 & 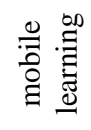 & 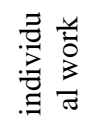 & $\begin{array}{l}\frac{0}{0} \\
\frac{0}{2} \\
\frac{0}{2}\end{array}$ & 胥 & 当 \\
\hline 4.7 & 36.0 & 60.9 & 62.2 & 28.1 & 32.8 & 40.6 & 45.2 & 50.0 & 34.3 \\
\hline
\end{tabular}

However, they do not assess the importance and the influence of modern methods and activities very high. The variables of the availability of e-learning and online courses, that of MOOCs, and the opportunity of academic mobility of students were considered not very important. Parallel with this, they neither evaluate the effectiveness of online courses and mobile learning very high. It means that Hungarian students adhere to the good-old, well-known practical training.

\section{Conclusion}

Today's generation of students is techno-savvy: they are significantly adaptable to innovation trends and immediately use emerging and up-to-date technologies, as well as info-communication devices both in their studies and work. They prefer audio-visual materials and consider learning more effective with sharing information through video format content. Regarding teachers, they have to face the challenge to meet the needs of the digital generation through applying new technology, implementing it into the teaching-learning process, and so, changing teaching methodology. There are many modern technologies are available for teachers, especially in higher education. [45]

The results of the research show some contradiction with the expectations. Students, especially the Hungarian ones, prefer the practical elements in their training: they declared that the factors most affecting the quality of their training are closely related to laboratory work, internship, and labor market expectations. 
On the other hand, the availability of e-learning and access to MOOC are considered to be much less significant. Regarding the methods used by the teachers, students evaluated the most effective the ones that are in connection with practice: internship and practical lesson - while the least effective online courses. What is more, online courses are assumed less effective them lectures and examination - the good-old teaching methods, which have been existed in higher education for centuries.

This contradiction draws the focus on some problems and makes researchers ask some questions - which, of course, needs further examination. Do teachers apply the digital methodology in their lessons or they think it is time-consuming and nothing but having fun with students? Do online courses that are available for the majority of students meet the needs of today's students using $21^{\text {st }}$-Century technology and providing a platform for interactivity and collaboration? Researchers assume that professors of engineer faculties would need training focusing on the application of up-to-date technology, as well as teaching methods and work forms.

\section{Acknowledgment}

This research was supported by EFOP-3.6.1-16-2016-00003 grants, Establishment of long-term R \& D \& I process at the University of Dunaujvaros.

\section{References}

[1] Kovari, A.: Adult education 4.0 industry 4.0 challenges in lifelong learning, PedActa, Vol. 9, No. 1, 2019, pp. 9-16

[2] Brady, S.: How Generation $\mathrm{Z}$ is Changing the Rules in Future Visions: Understanding Generation Z, 2019, https://www.rga.com/futurevision/ magazine/futurevision-understanding-generation- $z$ [Date of download 07. 07. 2019.]

[3] Baranyi, P., Csapó, Á.: Definition and Synergies of Cognitive Infocommunications. In: Acta Polytechnica Hungarica. Vol. 9, No. 1, 2012, pp. $67-83$

[4] Adrás, I. et al.: HASIT: 3. Subprogram. Training the Trainers. (Alprogram Képzők Képzése) DUE Press. Dunaújváros. 2016, pp. 8-9

[5] Verhagen, P.: Connectivism: A new learning theory. Surf e-learning theme site. 11. 2006, https://www.scribd.com/doc/88324962/Connectivism-aNew-Learning-Theory [Date of download: 02. 03. 2020.]

[6] Cserné Adermann, G.: Learning Theories for the Virtual University. (Tanuláselméletek a Virtuális Egyetemhez) In: Kadocsa, L. -Németh, I. P. (2015) (edit.): Virtual University. (Virtuális Egyetem) Dunaújváros: DUF Press. 2015, pp. 69-87 
[7] Ujbanyi, T. et al.: ICT Based Interactive and Smart Technologies in Education - Teaching Difficulties. International Journal of Management and Applied Science, Vol. 3, No. 10, 2017, pp. 72-77

[8] Racsko, R.: Digital Transformation in Education. (Digitális átállás az oktatásban) Veszprém: School Culture Books (Iskolakultúra-könyvek) 52, 2017

[9] Horvath, I., Sudar A.: Factors contributing to the enhanced performance of the Maxwhere 3d VR platform in the distribution of digital information. Acta Polytechnica Hungarica, Vol. 15, No. 3, 2018, pp. 149-173

[10] Nagy, K., et al.: Gamification and microcontent orientated methodological solutions based on bring-your-own-device logic in higher education, IEEE, Proceedings of the $9^{\text {th }}$ IEEE International Conference on Cognitive Infocommunications: CogInfoCom, Budapest, 2018, pp. 385-388

[11] Gilányi, A., Chmielewska, K.: Educational Context of Mathability. Acta Polytechnica Hungarica, Vol. 15, No. 5, 2018, pp. 223-237

[12] Jambor, S.: Educational methods based on student activity in vocational education. Transactions on IT and Engineering Education, Vol. 2, No. 1, 2019, pp. 17-29

[13] Pinter, R., Maravic Cisar, S.: "B here" - Class Attendance Tracking System with Gamification. 10 $10^{\text {th }}$ IEEE International Conference on Cognitive Infocommunications, Naples, Italy, 2019, pp. 271-276

[14] Muhi, B. B., Körösi G., Esztelecki P.: Pedagogical Opportunities of mLearning applications. (Az m-learning alkalmazásának pedagógiai lehetôségei) In: Information Society. (Információs Társadalom) 2015, https://www.researchgate.net/publication/298792089 [Date of download 07. 06. 2019.]

[15] Gogh, E., Kovari, A.: Experiences of Self-regulated Learning in a Vocational Secondary School. Journal of Applied Technical and Educational Sciences, Vol. 9, No. 2, 2019, 72-86

[16] Schrauf, G.: Importance of project-based learning in software development. Computers \& Learning, Vol. 2, No. 1, 2019, pp. 27-39

[17] Bérci, R.: Game development through independent student activities. Computers \& Learning, Vol. 1, No. 1, 2001, pp. 26-38

[18] Orosz, B., et al.: Digital education in digital cooperative environments. Journal of Applied Technical and Educational Sciences, Vol. 9, No. 4, 2019, pp. 55-69

[19] Tick, A.: An Extended TAM Model, for Evaluating eLearning Acceptance, Digital Learning and Smart Tool Usage. Acta Polytechnica Hungarica, Vol. 16, No. 9, 2019, pp. 213-233 
[20] Namestovski, Z., et al.: External Motivation, the Key to Success in the MOOCs Framework. Acta Polytechnica Hungarica, Vol. 15, No. 6, 2018, pp. $125-142$

[21] Bartal, O.: Attitude Survey among Parents and Teachers regarding the Application of BYOD Method in Upper Classes of a Primary School in Tolna County (Attitüd-vizsgálat a szülők és a pedagógusok körében a BYOD-módszer tanórai alkalmazásának tekintetében egy tolna-megyei általános iskola felső tagozatán). In: Varga, A., Andl, H., Molnár-Kovács, Z. (edit.) Educational Science - Horizons and Dialogues. Pécs, Hungarian Academy of Sciences, Pedagogical Scientific Committee, (Neveléstudomány - Horizontok és dialógusok. MTA Pedagógiai Tudományos Bizottság) 2019, pp. 351-351

[22] Csikósné, M. E.: Opportunities for Applying Gamification in Higher Education (A gamifikáció felsőoktatási alkalmazásának lehetőségei). Training and Practice. (Képzés és Gyakorlat) Vol. 17, No. 3-4, 2019, pp. 23-31

[23] Key Competencies Suitable for Life-Long Learning. https://ofi.oh.gov.hu/tudastar/nemzetkozi-kitekintes/egesz-eleten-at-tarto [Date of download: 13.10.2017.]

[24] Ala-Mutka, K.: Mapping Digital Competence: Towards a Conceptual Understanding. European Commission Joint Research Centre Luxembourg. 2011, ftp://jrc.es/pub/EURdoc/JRC67075_TN.pdf [Date of download: 30.08.2018.]

[25] Horváth, I.: Innovative engineering education in the cooperative VR environment. $7^{\text {th }}$ IEEE International Conference on Cognitive Infocommunications (CogInfoCom) Wroclaw, Poland, 2016, pp. 359-364

[26] Katona, J., Kovari, A.: Examining the learning efficiency by a braincomputer interface system. Acta Polytechnica Hungarica, Vol. 15, No. 3, 2018, pp. 251-280

[27] Lakatosné Török E., Kárpáti A.: Correlation between IT Competence, Pedagogical Practice, and Innovation Success in the Hungarian Group Trying European Digital Learning Material Portal (Az informatikai kompetencia, a pedagógiai gyakorlat és az innovációs sikeresség összefüggései az Európai Digitális Tananyagportál magyar kipróbálói csoportjában) Hungarian Pedagogy (Hungarian Pedagogy) Vol. 3, 2009, pp. 227-259

[28] Prievara, T.: Teacher in the $21^{\text {st }}$ Century (A 21. századi tanár) Neteducation Kft. Budapest 2015

[29] Jukes, I., Dosaj, A.: The disconnect: what causes this disconnect? http://okt.ektf.hu/data/szlahorek/file/kezek/06_blended_04_11/523prensky_ terminolgija.html 2003 [Date of download: 07. 04. 2019.] 
[30] Szabó, Cs. M.: Could the Gap be Bridged in Education between Digital Natives and Digital immigrants? (Áthidalható-e a szakadék az oktatásban a digitális bennszülöttek és a digitális bevándorlók között?) In: HulyákTomesz, T. (edit.): Education of Communication 11: Generation Questions in Development of Communication Skills (A kommunikáció oktatása 11: Generációs kérdések a kommunikációs készségfejlesztésben) Budapest, Hungarovox Publishing, 2019, pp. 9-22

[31] Szabó, Cs. M.: Behavior of Adolescence - Active Internet Users: Results of the Research of Teachers in Hungary and Russia (Поведение подростков - активных пользователей интернета: результаты исследования педагогов Венгрии и России). In: Panov, I. (edit): Eco-psychological Researches 6: Ecology of Childhood and Psychology of Sustainable Development (Экопсихологические развития-6: экология дества и психология устойчбого развития). Kurks, University Book Ltd. 2020, pp. 491-495

[32] Szabó, Cs. M.: Digital competence of teachers - how do we teach generation z? In: András, I.; Rajcsányi-Molnár, M. (edit.) East West Cohesion III: Strategical study volumes. Subotica, Serbia: Čikoš Group 2019, pp. 197-206

[33] Nagy, B., Váraljai, M., Mihalovicsné Kollár, A.: E-learning Spaces to Empower Students Collaborative Work Serving Individual Goals. In: Acta Polytechnica Hungarica. Vol. 17, No. 2, 2020, pp. 97-114

[34] Benedek, A., Molnár, Gy.: New methodical approach to the VET teachers' training. In: Stalder, Barbara; Nägele, Christof - Trends in vocational education and training research, Vol. II, Proceedings of the European Conference on Educational Research (ECER), Vocational Education and Training Network (VETNET) Hamburg, Germany: Vocational Education and Training Network, 2019, pp. 68-76, https://zenodo.org/record/ 3371432\#.XkvItShKjIU7 [Date of download: 02. 03. 2020.]

[35] Ujbányi, T., Stankov, G., Nagy, B.: A transparent working environment in MaxWhere virtual space. In: Baranyi, P. (edit.) Proceedings of the $10^{\text {th }}$ IEEE International Conference on Cognitive Infocommunications: CogInfoCom 2019, Piscataway (NJ), USA: IEEE, 2019, pp. 475-478

[36] Small, G. W., Morgan, G.: iBrain: Surviving the technological alteration of the modern mind. HarperCollins Publishers 2009

[37] Carr, N.: How is the Internet Changing our Brain? - The Era of the Shallow-minded. (Hogyan változtatja meg agyunkat az internet? - A sekélyesek kora) HVG Books 2014

[38] Szőke-Milinte, E: Getting to Know Generation Z - Gaining Information in Generation $\mathrm{Z}$ (A $\mathrm{Z}$ generáció megismerése - megismerés a $\mathrm{Z}$ generációban). In: Kaposi J. - Szőke-Milinte E. (edit): Pedagogical Changes - Changes in Pedagogy (Pedagógiai változások - a változás 
pedagógiája). Budapest: Professional Knowledge Publishing House (Szaktudás Kiadó Ház) 2019, pp. 130-144

[39] Prensky, M.: Digital Natives, Digital Immigrants. Part II. Do They Really Think Differently? In: On the Horizon NCB University Press, Vol. 9, No. 6, 2001, https://www.marcprensky.com/writing/Prensky\%20\%20Digital\%20Natives, \%20Digital\%20Immigrants\%20-\%20Part2.pdf

[Date of download: 10. 02. 2019.]

[40] Bound, D., Cohen, R., Sampson, J.: Peer Learning and Assessment. In: Assessment \& Evaluation in Higher Education. Vol. 24, No. 4, 1999, pp. 413-426, https://www.tandfonline.com/doi/abs/10.1080/ 0260293990240405 [Date of download: 12. 04. 2019]

[41] Settles, B.: Active Learning Literature Survey. University of WisconsinMadison 2009, https://minds.wisconsin.edu/bitstream/handle/1793/ 60660/TR1648.pdf?sequence $=1$ [Date of download: 12. 02. 2020]

[42] Felder, R. M., Brent, R.: Active Learning: An Introduction. https://www.engr.ncsu.edu/wp-content/uploads/drive/ 1YB2KK3wLqP3EhXyYdKtE9-4mBJzc2rc2/

Active\%20Learning\%20Tutorial.pdf [Date of download: 12. 02. 2020]

[43] Kumar, M. P., Packer, B., Koller, D.: Self-Paced Learning for Latent Variable Models. https://papers.nips.cc/paper/3923-self-paced-learning-forlatent-variable-models.pdf [Date of download: 12. 02. 2020]

[44] Jiang, L. et.al.: Self-Paced Curriculum Learning. In: Proceedings of the Twenty-Ninth AAAI Conference on Artificial Intelligence 2015, pp. 26942700, https://www.aaai.org/ocs/index.php/AAAI/AAAI15/paper/viewFile/ 9750/9929 [Date of download: 12. 02. 2020]

[45] Váraljai, M., Nagy, B.: A Survey in Issues of Disruptive Technologies to Broaden Learning for The Future Students. In: Baranyi, P. (edit.) Proceedings of the $10^{\text {th }}$ IEEE International Conference on Cognitive Infocommunications: CogInfoCom 2019, Piscataway (NJ), USA: IEEE, 2019, pp. 391-396 